\title{
Integrative review of factors related to the nursing diagnosis nausea during antineoplastic chemotherapy ${ }^{1}$
}

\author{
Aline Maria Bonini Moysés² \\ Lais Corsino Durant ${ }^{3}$ \\ Ana Maria de Almeida ${ }^{4}$ \\ Thais de Oliveira Gozzo 5
}

\begin{abstract}
Objective: to identify factors related to the nursing diagnosis nausea among cancer patients undergoing chemotherapy. Method: integrative review conducted in four electronic databases (PUBMED, EMBASE, CINAHL and LILACS) using the key words: neoplasia, antineoplastic agents and nausea. Results: only 30 out of 1,258 papers identified met the inclusion criteria. The most frequent related factors were: being younger than 50 years old, motion sickness, being a woman, emetogenic potential of the chemotherapy, anxiety, conditioned stimulus, and expecting nausea after treatment. Conclusion: this review's findings, coupled with the incidence of nausea among cancer patients undergoing chemotherapy, reveal an important difference between evidence found and that used by NANDA International, Inc. Even though it provides an appropriate definition of related factors, it does not mention chemotherapy, despite the various studies addressing the topic using different designs and presenting various objectives and outcomes.
\end{abstract}

Descriptors: Nausea; Chemotherapy; Neoplasms; Nursing Diagnosis; Review Literature as Topic.

\footnotetext{
${ }^{1}$ Paper extracted from Master's Thesis "Concept analysis of diagnosis of nause during chemothepay treatment in nursing" presented to Escola de Enfermagem de Ribeirão Preto, Universidade de São Paulo, PAHO/WHO Collaborating Centre for Nursing Research Development, Ribeirão Preto, SP, Brazil.

2 MSc, RN, Hospital das Clínicas, Faculdade de Medicina de Ribeirão Preto, Universidade de São Paulo, Ribeirão Preto, SP, Brazil.

${ }_{3}^{3}$ Master's student, Escola de Enfermagem de Ribeirão Preto, Universidade de São Paulo, PAHO/WHO Collaborating Centre for Nursing Research Development, Ribeirão Preto, SP, Brazil.

${ }^{4}$ PHD, Associate Professor, Escola de Enfermagem de Ribeirão Preto, Universidade de São Paulo, PAHO/WHO Collaborating Centre for Nursing Research Development, Ribeirão Preto, SP, Brazil.

${ }^{5}$ PHD, Professor, Escola de Enfermagem de Ribeirão Preto, Universidade de São Paulo, PAHO/WHO Collaborating Centre for Nursing Research Development, Ribeirão Preto, SP, Brazil.
}

\section{How to cite this article}

Moysés AMB, Durant LC, Almeida AM, Gozzo TO. Integrative review of factors related to the nursing diagnosis nausea during antineoplastic chemotherapy. Rev. Latino-Am. Enfermagem. 2016;24:e2812. [Access

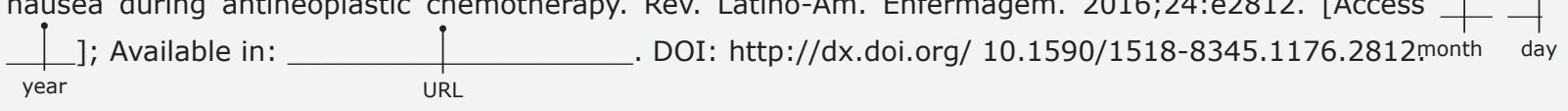




\section{Introduction}

The incidence of nausea during chemotherapy ranges from 37 to $70 \%{ }^{(1)}$. This incidence is mainly related to the emetogenic potential of chemotherapeutic drugs associated with the individual variations of each patient. Being aware of a drug's emetogenic potential and the characteristics of this adverse event in terms of peak and interval of occurrence is key and essential for the practice of oncologic nursing(2).

The ability to control vomiting during chemotherapy has improved considerably in recent years, essentially with regard to drug management, with the development and use of new and modern antiemetic drugs. Controlling nausea, however, seems to be a challenge(3), and yet the healthcare staff and patients themselves have neglected this symptom.

Some of the likely reasons chemotherapy-induced nausea is difficult to control include: the subjectivity of the symptom, lack of focus when assessing it, lack of validated instruments, limited understanding of physiopathology, inefficient record of this event on the part of patients, and failure on the part of nurses to assess its impact in the lives of patients, especially quality of life ${ }^{(4)}$.

The impact of nausea on the patients' nutritional status and quality of life become evident few days after chemotherapy. Because in most cases the treatment is administered in an outpatient clinic, this symptom that requires careful assessment is neglected, hindering specific clinical management and nutritional interventions, in addition to the combination of pharmacological and non-pharmacological therapies(5).

The identification and planning of nursing care concerning the nursing diagnosis (ND) nausea values the work of nurses in the Oncology field and improves the quality of care provided to patients. For this reason, investigating the factors related to this diagnosis is key. Factors related to the ND nausea can favor management and allow the nursing staff to devise a care plan that enables the implementation of efficacious and immediate actions to solve problems ${ }^{(6)}$.

Given the previous discussion, this study's objective was to identify the factors related to the nursing diagnosis nausea among cancer patients during chemotherapy through an integrative review.

\section{Method}

An integrative review involves six $\operatorname{steps}^{(7-8)}$ : identifying the theme and establishing the guiding question or hypothesis, establishing inclusion and exclusion criteria, literature search, deciding on what information will be extracted from the studies selected, assessing the studies included in the review, interpreting results, and synthesizing knowledge.

This integrative review's aim was to answer the guiding question: What is the evidence available regarding nausea-related factors among cancer patients undergoing antineoplastic chemotherapy? For that, a bibliographic search was conducted in four databases: PUBMED (United States National Library of Medicine), LILACS (Latin American and Caribbean Health Sciences Literature), CINAHL (Cumulative Index to Nursing and Allied Health Literature) and EMBASE (Excerpta Medica Database). The search was performed in May 2013, as part of a larger study intended to validate the nursing diagnosis Nausea. No time limit was established for the inclusion of papers.

Controlled descriptors used in the search strategies included: neoplasms, antineoplastic agents and nausea. It is important to note that there were variations, especially with regard to non-controlled descriptors in the different databases, as shown in Figure 1. CINAHL did not present non-controlled descriptors. The Boolean operator AND was used with controlled descriptors and OR was used for non-controlled descriptors; NOT was also used for radiotherapy, surgery, metastasis and chemotherapy.

\begin{tabular}{|c|l|}
\hline Databases & \multicolumn{1}{c|}{ Non-controlled descriptors } \\
\hline \multirow{2}{*}{ PUBMED } & $\begin{array}{l}\text { Tumors; tumor; neoplasia; neoplasm; cancer; cancers } \\
\text { drug, Chemotherapeutic Anticancer; antitumor Drugs; drugs, Antitumor; cancer Chemotherapy Agents; agents, Cancer } \\
\text { Chemotherapy chemotherapy Agents, Cancer; cancer Chemotherapy Drugs; chemotherapy Drugs, Cancer; drugs, } \\
\text { Cancer Chemotherapy; chemotherapeutic Anticancer Agents; agents, Chemotherapeutic Anticancer; Anticancer agents; } \\
\text { agents, Anticancer; antitumor Agents; agents, Antitumor }\end{array}$ \\
\hline
\end{tabular}




\begin{tabular}{|c|c|}
\hline Databases & Non-controlled descriptors \\
\hline & $\begin{array}{l}\text { Acral tumor; cancer; cancers; neoplasia; neoplasms; neoplasms by histologic type; neoplasms, cystic, mucinous, serous; } \\
\text { neoplasms, embryonal mixed; neoplasms, germ cell embryonal; neoplasms, glandular epithelial; neoplasms, 'hormone } \\
\text { dependent' neoplasms, 'post traumatic'; neoplastic disease; section 16; tumor; tumor }\end{array}$ \\
\hline EMBASE & $\begin{array}{l}\text { Anti cancer drug; anti neoplastic agent; anticancer agent; anticancer drug; anticancerogen; anticarcinogen; } \\
\text { anticarcinogenic agents; antineoplastic agents; antineoplastic agents, combined; antineoplastic agents, phytogenic; } \\
\text { antineoplastic immunosuppressive agents; antineoplastic combined chemotherapy protocols; antineoplastic drug; } \\
\text { antineoplastic peptide; antitumor agent; antitumor drug; cancer chemotherapeutic agent; cancer inhibitor; carcinostatic } \\
\text { drug; drug, antineoplastic; tumor inhibitor }\end{array}$ \\
\hline \multirow{3}{*}{ LILACS } & Neoplasias; câncer; cancro (tumor maligno); neoplasmas; tumor; tumores; neoplasia; neoplasia maligna \\
\hline & Antineoplásicos; antineoplásicos; agentes antineoplásicos; fármacos antineoplásicos \\
\hline & Náusea; enjoo \\
\hline
\end{tabular}

Figure 1 - Distribution of databases according to non-controlled descriptors used to search for studies to be included in the integrative review. Ribeirão Preto, SP, Brazil, 2013.

Criteria used to include papers were: full texts of primary studies addressing nausea in humans undergoing intravenous antineoplastic chemotherapy; written in Portuguese, English or Spanish. Exclusion criteria were: letters, editorials, case studies, pilot studies; papers addressing patients with advanced or metastatic cancer or receiving palliative treatment concomitantly with antineoplastic chemotherapy.

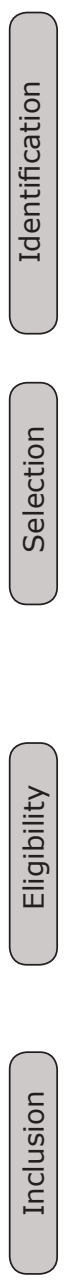

Papers identified in the databases:

PUBMED (927); EMBASE (278); CINAHL (34); LILACS (190)

$$
(n=1,258)
$$

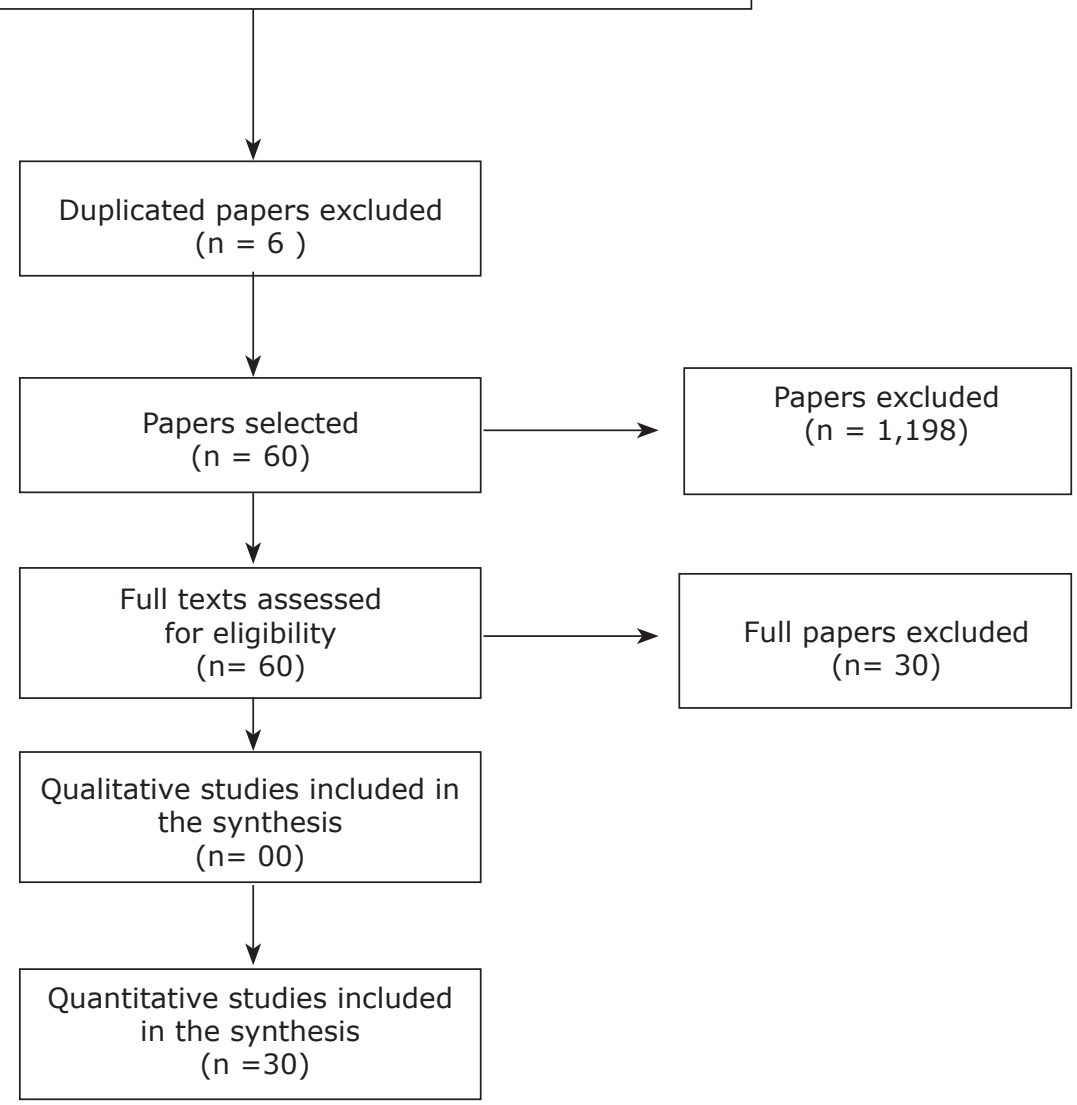

Figure 2 - Flowchart of identification, selection, and inclusion of studies. 
After the study authors reached a consensus regarding relevant information in each study, data were synthesized. Thus, all papers in the sample were read, aiming to explore the texts and extract data using an instrument ${ }^{(9)}$ addressing the following items: identification of studies, introduction, objectives, methodological characteristics, results and conclusions. The instrument was completed for all the papers, which were cataloged in ascending order according to year of publication.

All data concerning the characteristics of each study, as well as information regarding nausea-related factors among cancer patients undergoing chemotherapy were grouped in tables and analyzed descriptively.

The studies' level of evidence was classified according to Melnyk and Fineout-Overholt(10), following the classification: Level 1 - strong evidence (systematic review or meta analysis); Level 2 - strong evidence (welldesigned randomized controlled clinical trials); Level 3 moderate evidence (non-randomized controlled clinical trials); Level 4 - moderate evidence (case control or cohort studies); Level 5 - weak evidence (systematic reviews, descriptive and qualitative studies); Level 6 weak evidence (descriptive or qualitative studies); Level 7 - weak evidence (opinion of authorities and/or reports of expert committees). To apply this classification, we first identified the design of each study; only 17 out of the 30 studies presented this information. Two researchers determined the designs of the remaining studies after reading the texts.

\section{Results}

The final sample comprised 30 studies $^{(11-40)}, 29$ of which were indexed in PUBMED and one in EMBASE; 29 were published in English and one in Spanish.
The number of authors ranged from one to seven; most $(78.6 \%)$ studies were written by up to three authors. Considering the large number of authors, we opted to characterize only the primary author: six papers were authored by psychologists, four by physicians, four by pharmacists, three were written by nurses, and the background of the authors of 11 papers was not identified.

With regard to the studies' settings, 10 studies were multicenter studies and 16 were conducted at a single center - Oncology day hospitals, General Hospitals or Clinical Research Centers among others; four studies did not report the study setting.

With regard to the country of origin of the primary author, 17 were from the United States of America, three from Spain, two from Greece, one from Sweden, one from Colombia, one from the United Kingdom, one from Austria, one from Thailand, one from Singapore and one from Malaysia.

The periodicals the papers were published in belonged to different health fields: three were from the field of psychology, four from the medical field, two from the field of pharmacy, three journals published papers from the medical and psychology field, and 18 journals were interdisciplinary. Interdisciplinary journals published most $(60 \%)$ of the papers, including those from the nursing fields.

Because a time limit was not established, the sample included papers published between 1985 and 2012: one was from the 1980s, 10 papers were from the 1990s, 15 were published between 2000 and 2009 and four papers were published from 2010 to 2012.

As shown in Figure 3, the sample was composed of 12 studies with evidence level 6, 14 studies with evidence level 4 , one study with evidence level 3, and three studies with evidence level 2.

\begin{tabular}{|c|c|l|c|}
\hline Reference & Year of publication & \multicolumn{1}{|c|}{ Design } & Evidence level \\
\hline 11 & 1985 & Cross-section, descriptive $^{*}$ & 6 \\
\hline 12 & 1991 & Longitudinal $^{\dagger}$ & 4 \\
\hline 13 & 1992 & Longitudinal, descriptive $^{*}$ & 4 \\
\hline 14 & 1992 & Randomized controlled clinical trials $^{*}$ & 2 \\
\hline 15 & 1992 & Transversal, descriptive $^{*}$ & 6 \\
\hline 16 & 1993 & Exploratory, observational $^{\dagger}$ & 3 \\
\hline 17 & 1994 & Non-randomized controlled clinical trial $^{*}$ & 6 \\
\hline 18 & 1995 & Descriptive $^{\dagger}$ & 4 \\
\hline 19 & 1996 & Longitudinal, prospective $^{\dagger}$ & 6 \\
\hline 20 & 1997 & Descriptive $^{*}$ & 4 \\
\hline 21 & 1998 & Retrospective $^{\dagger}$ & 6 \\
\hline 22 & 2000 & Transversal, descriptive $^{*}$ & 6 \\
\hline
\end{tabular}




\begin{tabular}{|c|c|c|c|}
\hline Reference & Year of publication & Design & Evidence level \\
\hline 23 & 2000 & Transversal, descriptive ${ }^{*}$ & 6 \\
\hline 24 & 2000 & Longitudinal, descriptive* & 4 \\
\hline 25 & 2000 & Transversal, descriptive* & 6 \\
\hline 26 & 2001 & Prospective $^{\dagger}$ & 4 \\
\hline 27 & 2002 & Longitudinal, prospective $^{\dagger}$ & 4 \\
\hline 28 & 2003 & Descriptive* $^{*}$ & 6 \\
\hline 29 & 2004 & Transversal, multicenter and prospective ${ }^{\dagger}$ & 6 \\
\hline 30 & 2004 & Randomized controlled clinical trial ${ }^{\dagger}$ & 2 \\
\hline 31 & 2006 & Prospective, multicenter and observational ${ }^{\dagger}$ & 4 \\
\hline 32 & 2006 & Descriptive* $^{*}$ & 6 \\
\hline 33 & 2006 & Prospective $^{\dagger}$ & 4 \\
\hline 34 & 2007 & Longitudinal, prospective $^{\dagger}$ & 4 \\
\hline 35 & 2008 & Randomized controlled clinical trial $^{\dagger}$ & 2 \\
\hline 36 & 2009 & Prospective, observational ${ }^{\dagger}$ & 4 \\
\hline 37 & 2010 & Descriptive* & 6 \\
\hline 38 & 2010 & Prospective $^{\dagger}$ & 4 \\
\hline 39 & 2010 & Longitudinal, prospective, observational ${ }^{\dagger}$ & 4 \\
\hline 40 & 2012 & $\begin{array}{l}\text { Multi center, prospective, } \\
\text { observational }^{\dagger}\end{array}$ & 4 \\
\hline
\end{tabular}

*Type of study according to this study's authors; † Type of study reported by the papers' authors.

Figure 3 - Distribution of studies included in the integrative review according to year of publication, design, and level of evidence. Ribeirão Preto, SP, Brazil, 2013

A total of 44 related factors were extracted from the studies included in the integrative review: 25 (56.8\%) were related to patient, $11(25 \%)$ related to psychological factors, and eight (18.2\%) factors were related to treatment. The most frequent were: being younger than 50 years of age, motion sickness, being a woman, anxiety, conditioned stimuli, expecting nausea after treatment, and the emetogenic potential of the chemotherapy. Figure 4 presents the most frequent related factors reported in the studies.

\begin{tabular}{|l|c|}
\hline \multicolumn{1}{|c|}{ Factors related } & N (\%) \\
\hline To the patient & $14(46.7)$ \\
\hline Younger than 50 years old & $11(36.7)$ \\
\hline Motion sickness & $10(33.3)$ \\
\hline Female sex & $6(20)$ \\
\hline Nausea during pregnancy & $5(16.7)$ \\
\hline Low consumption of alcohol & $2(6.7)$ \\
\hline Prior experience with chemotherapy & $2(6.7)$ \\
\hline Nausea in previous cycles & $2(6.7)$ \\
\hline Performance status & $2(6.7)$ \\
\hline Weight loss & $2(6.7)$ \\
\hline Severity of nausea in previous cycle & $2(6.7)$ \\
\hline Toxins (non specified) & $10(33.3)$ \\
\hline To the treatment & $5(16.7)$ \\
\hline Emetogenic potential of chemotherapy & $3(10)$ \\
\hline Chemotherapy agents & \\
\hline Doses of chemotherapy & \\
\hline
\end{tabular}




\begin{tabular}{|l|c|}
\hline \multicolumn{1}{|c|}{ Factors related } & N (\%) \\
\hline Number of cycles or prior exposure to chemotherapy & $3(10)$ \\
\hline Use of antiemetics & $3(10)$ \\
\hline Combination of chemotherapy agents & $2(6.7)$ \\
\hline Type of antiemetics prescribed & $2(6.7)$ \\
\hline Psychological factors & $9(30)$ \\
\hline Anxiety & $9(30)$ \\
\hline $\begin{array}{l}\text { Conditioned stimuli: clinic's eyesight, smell, and sounds, the nurse's voice, colors of the chemotherapy drugs, the } \\
\text { physician's eyesight. }\end{array}$ & $7(23.3)$ \\
\hline Expectation of nausea after treatment & $3(10)$ \\
\hline Anguish & $3(10)$ \\
\hline General psychological stress & $3(10)$ \\
\hline Family support/conflicts & $2(6.7)$ \\
\hline Expectation of response after treatment & \\
\hline
\end{tabular}

Figure 4 - Distribution of absolute $(\mathrm{N})$ and relative (\%) frequency of factors related to nausea in the studies included in the integrative review. Ribeirão Preto, SP, Brazil, 2013

\section{Discussion}

The most frequent factor related to the ND nausea while undergoing chemotherapy was being younger than 50 years old, which was reported by 14 studies $^{(12-13,20-21,23,26-28,30,32,35-38)}$. Young patients more frequently reported acute and late nausea induced by antineoplastic chemotherapy than older patients in all the treatment cycles $^{(41)}$, and also reported that these symptoms negatively impacted their daily lives ${ }^{(42)}$.

One study aimed to assess the predictive power of personal characteristics related to the development of chemotherapy-induced nausea and vomiting (CINV) in a heterogeneous sample of 991 patients with different types of cancer, concluding that the key variables that characterized antecedents for nausea included: not using antiemetic medication according to international guidelines, being young, experiencing nausea before chemotherapy, and inappropriate response to CINV in previous cycle ${ }^{(43)}$.

Among the factors related to patients, we highlight susceptibility to motion sickness, also known as kinetosis, which was identified in 11 studies $^{(12,15,20,22-23,26-27,30,35-37)}$.

Motion sickness causes discomfort when movement disturbs the organs responsible for balance. It refers to a combination of autonomic and cognitive signs and symptoms induced when exposed to certain types of movement and may include nausea, vomiting, paleness, cold sweats, hyper salivation, and headache. The control and prevention of these symptoms include pharmacological, behavioral and complementary therapies ${ }^{(44-45)}$.

The Aurélio dictionary emphasizes, in its definition of nausea, that motion sickness is an "unpleasant sensation, well described by familiar expressions, such as having a gag reflex and upset stomach. Associated to feeling nauseated when travelling, especially on water." ${ }^{\prime \prime 6)}$

A prospective observational study conducted with 213 women with gynecological cancer, which aimed to investigate risk factors for CINV, revealed that being young, motion sickness and the high emetogenic potential of chemotherapy are associated with late nausea(47).

Another individual factor was the patient's sex. Nausea was more frequently identified among women than among men $(20-21,23,27,28,30,35-38)$. The same was observed with regard to acute nausea, which affected $48 \%$ of women compared to $18 \%$ of men, as well as for late nausea, which affected $75 \%$ of women versus $51 \%$ of men ${ }^{(40)}$.

The incidence of more frequent nausea and vomiting among women may be explained by the frequent use of protocols with higher emetogenic potential and a low consumption of alcohol(48).

Data also reported by a study investigating risk factors show that female patients are significantly more likely to experience CIVN. Additionally, the following risk factors stand out in the acute phase: being a woman, younger than 55 years of age, and non-habitual consumption of alcohol. In the late phase, only being a woman is a risk factor for CIVN (49).

The studies under analysis also reported that the emetogenic potential of chemotherapy agents was the most frequent related factor, which was identified in 10 studies $^{(13-14,17,20,22-23,31,35,38,40)}$. 
Some factors that triggered CINV are related to the treatment, including the antiemetic regimen adopted, the specific agent, dose of chemotherapy, route and speed of administration. Short intravenous infusions more frequently induce vomiting than prolonged infusions or oral medications ${ }^{(48)}$.

Patients treated with highly emetogenic antineoplastic chemotherapy were 5.61 times more likely to experience chemotherapy-induced nausea and vomiting in the first cycle than when treated with moderately emetogenic protocols ${ }^{(41)}$. The occurrence of anticipatory nausea was also significantly associated with the high emetogenic potential of chemotherapy ${ }^{(50)}$.

Being a woman and moderate to highly emetogenic chemotherapy stood out among the risk factors that trigger nausea(51).

With regard to psychological factors, anxiety was the most frequently reported in research ${ }^{(11,13,20,25-27,34,36-37)}$. Some anxiety symptoms, such as fear of death, fear for the worse, inability to relax, hot or cold sweats, nervousness, weakness, and numbness were identified as potential indicators of chemotherapy-induced nausea and vomiting(52). Similarly, the level of pre-treatment anxiety and expectation of nausea and vomiting were strongly associated with the development of severe symptoms ${ }^{(53)}$.

A study conducted with 94 women with gynecological cancer, which employed the State-Trait Anxiety Inventory and a self-report questionnaire, reported that being young and anxiety levels are associated with a high risk of experiencing CINV(54).

The development of anticipatory nausea and vomiting better suits the Pavlovian conditioning model. In this model, a conditioned stimulus, such as the view of a nurse, is paired with an unconditioned stimulus, for instance chemotherapy, which produces an unconditioned response such as nausea. There are no data on the development, clinical progress, or treatment of anticipation adverse events that disagree with this model(55). Conditioned stimuli were reported in nine studies ${ }^{(11-14,16,19-20,27,34)}$ as being a factor related to chemotherapy-induced nausea.

After experiencing repetitive cycles in which stimuli are paired with subsequent nausea, cycles acquire the ability to trigger nausea and vomiting even before chemotherapy is administered ${ }^{(56)}$.

Expecting nausea after the treatment was reported in seven studies ${ }^{(13,23,26-27,30,33,35)}$ included in the integrative review. Patients classified as having a high expectation of experiencing nausea presented the highest mean of occurrence of nausea when compared to those classified as having low expectation(57).
The need to investigate nausea-related factors becomes evident, but such an investigation as well as the planning of nursing care should be individualized because factors related to each patient and the emetogenic potential of the regimen should be taken into account.

Note that the best method to avoid or decrease the intensity of nausea and vomiting is to properly prevent them from the first exposure to chemotherapy.

Still in this context, we draw attention to the inexistence of a ND risk for nausea in NANDA-I, which we believe to be relevant to patients who are about to initiate chemotherapy. Devising a way to prevent nausea, planning and implementing actions before the first cycle of chemotherapy is administered should be the focus of nursing care provided to this clientele in order to diminish its negative impact on the patients' nutritional status and quality of life.

There is a need for nurses to investigate the presence of the nausea-related factors reported in this study. Such an investigation, however, as well as the planning of nursing care should be individualized, taking into account the risk factors of each patient in addition to the emetogenic potential of each treatment regimen.

\section{Conclusion}

The most frequent factors related to the ND nausea presented by patients undergoing antineoplastic chemotherapy were: being young, being a woman, motion sickness, the emetogenic potential of chemotherapy, anxiety, conditioned stimulus, and expectation that nausea will be experienced after the treatment. Of these, only motion sickness and anxiety are factors related to the ND Nausea containing in the North American Nursing Diagnosis AssociationInternational (NANDA-I Inc), which shows an important difference between evidence found and that used by NANDA-I Inc.

This analysis shows that, although the current definition of nausea presented by NANDA-I Inc. is appropriate to patients undergoing chemotherapy, this definition does not include among its related factors "chemotherapy" or "antineoplastic chemotherapy", despite the various studies addressing this topic, using different designs and presenting different objectives and outcomes

Given this review's findings and the incidence of nausea among cancer patients undergoing chemotherapy, it is crucial to include the term "chemotherapy" or "antineoplastic chemotherapy" among the factors related to the ND Nausea presented by NANDA International, Inc. 


\section{References}

1. Pirri C, Bayliss E, Trotter J, Olver IN, Katris P, Drummond $\mathrm{P}$, et al. Nausea still the poor relation in antiemetic therapy? The impact on cancer patients' quality of life and psychological adjustment of nausea, vomiting and appetite loss, individually and concurrently as part of a symptom cluster. Support Care Cancer. [Internet]. 2013 [Acesso 5 jun 2013];21(3):735-48. Disponível em: http://link.springer.com/article/10.1007 \%2Fs00520-012-1574-9.

2. Molassiotis A, Saunders MP, Valle J, Lorigan P, Wardley $A$, Levine $E$, et al. A prospective observational study of chemotherapy-related nausea and vomiting in routine practice in a UK cancer center. Support Care Cancer. [Internet]. 2008 [Acesso 15 jun 2013];16(2):201-8. Disponível em: http://link.springer.com/article/10.1007 \%2Fs00520-007-0343-7.

3. Roila F, Herrstedt J, Aapro M, Gralla RJ, Einhon LH, Ballatori E, et al. Guideline update for MASCC and ESMO in the prevention of chemotherapy- and radiotherapyinduced nausea and vomiting: results of the Perugia consensus conference. Ann Oncol. [Internet]. 2010 [Acesso 8 jul 2013];21(5):232-43. Disponível em: http://annonc.oxfordjournals.org/content/21/suppl_5/ v232.long.

4. Molassiotis A, Helin AM, Dabbour R, Hummerston $S$. The effects of P6 acupressure in the prophylaxis of chemotherapy-related nausea and vomiting in breast cancer patients. Complement. Ther Med. [Internet]. 2007 [Acesso 15 jun 2013];15(1):3-12. Disponível em: http://www.complementarytherapiesinmedicine.com/ article/S0965-2299(06)00092-6/pdf.

5. Farrell C, Brearley SG, Pilling M, Molassiotis A. The impact of chemotherapy-related nausea on patients' nutritional status, psychological distress and quality of life. Support Care Cance.r [Internet]. 2013 [Acesso10 jul 2013];21:59-66. Disponível em: http://link.springer. com/article/10.1007\%2Fs00520-012-1493-9.

6. Nogueira MRA, Áfio CJ, Barros LM, Galvão MTG. Diagnósticos de enfermagem, fatores relacionados e de risco no pós-operatório de cirurgia bariátrica. Rev Esc Enferm USP. [Internet]. 2013 [Acesso 29 set 2015] ;47(1):168-175. Disponível em: http://www.scielo.br/ scielo.php?script $=$ sci_arttext\&pid $=$ S0080623420130 00100021\&lng=pt http://dx.doi.org/10.1590/S008062342013000100021.

7. Broome ME. Integrative literature reviews for the development of concepts. In:

Rodgers BL, Knafl KA. Concept development in nursing: foundations, techniques and applications. Philadelphia. WB Saunder; 2000;2:77-102.
8. Ganong LH. Integrative reviews of nursing research. Res Nurs Health. [Internet]. 1987 [Acesso 5 ago 2013];10(1):1-11. Disponível em: http://onlinelibrary. wiley.com/doi/10.1002/nur.4770100103/abstract;jsess ionid=4F6E8F5CDBCFB52947E8119B4F1DB92F.f01t02.

9. Pompeo DA, Rossi LA, Galvão CM. Revisão integrativa: etapa inicial do processo de validação de diagnóstico de enfermagem. Acta Paul Enferm. [Internet]. 2009 [Acesso 5 mai 2013];22:434-8. Disponível em: http:// www.scielo.br/pdf/ape/v22n4/a14v22n4.pdf.

10. Melnyk BM, Fineout-Overholt E. Evidence based practice in nursing \& healthcare: a guide to best practice. Philadelphia: Wolters Kluwer/Lippincott Williams \& Wilkins; 2011.

11. Komen RW, Redd WH. Personality factors associated with anticipatory nausea/vomiting in patients receiving cancer chemotherapy. Health Psychol. 1985;4(3):189202.

12. Morrow GR, Lindke J, Black PM. Anticipatory nausea development in cancer patients: replication and extension of a learning model. $\mathrm{Br} \mathrm{J}$ Psychol. 1991;82(1953):61-72.

13. Andrykowski MA, Gregg ME. The role of psychological variables in post-chemotherapy nausea: anxiety and expectation. Psychosom Med. [Internet]. 1992 [Acesso 15 jul 2013];54(1):48-58. Disponível em: http://www. ncbi.nlm.nih.gov/pubmed/1553401.

14. Bovbjerg DH, Redd WH, Jacobsen PB, Manne SL, Taylor KL, Surbone A, et al. An experimental analysis of classically conditioned nausea during cancer chemotherapy. Psychosom Med. [Internet]. 1992 [Acesso 15 jun 2013];54(6):623-37. Disponível em: http://www.ncbi.nlm.nih.gov/pubmed/1454956.

15. Morrow GR, Angel C, Dubeshter B. Autonomic changes during cancer chemotherapy induced nausea and emesis. $\mathrm{Br}$ ] Cancer. [Internet]. 1992 [Acesso 5 ago 2013];19(1):42-5. Disponível em: http://www.ncbi. nlm.nih.gov/pmc/articles/PMC2149622/.

16. Redd $W H$, Dadds $M R$, Futterman $A D$, Taylor $K L$, Bovbjerg DH. Nausea Induced by Mental Images of Chemotherapy. Cancer. [Internet]. 1993 [Acesso7 ago 2013];72(2):629-36. Disponível em: http://www.ncbi. nlm.nih.gov/pubmed/8319197.

17. Fredrikson M, Hursti TJ, Steineck G, Furst CJ, Borjesson S, Peterson C. Delayed chemotherapy-induced nausea is augmented by high levels of endogenous noradrenaline. $\mathrm{Br}$ J Cancer. [Internet]. 1994 [Acesso 8 out 2013];70(4):642-5. Disponível em: http://www. ncbi.nlm.nih.gov/pmc/articles/PMC2033385/.

18. Rhodes VA, Watson PM, McDaniel RW, Hanson $\mathrm{BM}$, Johnson $\mathrm{MH}$. Expectation and occurrence of postchemotherapy side effects nausea and vomiting. Cancer Pract. 1995;3(4):247-53. 
19. Schwartz MD, Jacobsen PB, Bovbjerg DH. Role of nausea in the development of aversions to a beverage paired with chemotherapy treatment in cancer patients. Physiol Behav. [Internet]. 1996 [Acesso 8 out 2013];59(4):659-63. Disponível em: http://www.sciencedirect.com/science/article/ pii/0031938495020969.

20. Tyc VL, Mulhern RK, Bieberich AA. Anticipatory nausea and vomiting in pediatric cancer patients: an analysis of conditioning and coping variables. J Dev Behav Pediatr. 1997;18(1):27-33.

21. Tsavaris N, Mylonakis N, Bacoyiannis C, Kosmas C, Kalergis G, Iakovidis V, et al. Factors that influence the antiemetic activity of metoclopramide to cisplatin based chemotherapy. Oncol Rep. [Internet]. 1998 [Acesso 9 out 2013];5(5):1147-55. Disponível em: http://www. ncbi.nlm.nih.gov/pubmed/9683826.

22. Morrow GR, Andrews PL, Hickok JT, Stern R. Vagal changes following cancer chemotherapy: implications for the development of nausea. Psychophysiology. [Internet]. 2000 [Acesso 5 out 2013] ;37(3):37884. Disponível em: http://onlinelibrary.wiley.com/ doi/10.1111/1469-8986.3730378/pdf.

23. Roscoe JA, Hickok JT, Morrow GR. Patient expectations as predictor of chemotherapy-induced nausea. Ann Behav Med. [Internet]. 2000 [Acesso 21 out 2013];22(2):121-6. Disponível em: http://link. springer.com/article/10.1007/BF02895775\#page-1.

24. Tsavaris N, Kosmas C, Mylonakis N, Bacoyiannis C, Kalergis G, Vadiaka M, et al. Parameters that influence the outcome of nausea and emesis in cisplatin based chemotherapy. Anticancer Res. 2000;20(6C):4777-84.

25. Blasco T, Pallarés C, Alonso C, López JJL. The role of anxiety and adaptation to illness in the intensity of postchemotherapy nausea in cancer patients. Span J Psychol. [intenet]. 2000 [Acesso 23 out 2013];3(1):4752. Disponível em: http://revistas.ucm.es/index.php/ SJOP/article/viewFile/SJOP0000110047A/29501.

26. Hickok JT, Roscoe JA, Morrow GR. The role of patients expectations in the development of anticipatory nausea related to chemotherapy for cancer. J Pain Symptom Manage. [Internet]. 2001 [Acesso 22 out 2013];22(4):843-50. Disponível em: http://www. jpsmjournal.com/article/S0885-3924(01)00317-7/pdf.

27. Molassiotis A, Yam BM, Yung H, Chan FY, Mok TS. Pretreatment factors predicting the development of postchemotherapy nausea and vomiting in Chinese breast cancer patients. Support Care Cancer. [Internet]. 2002 [Acesso 24 ago 2013];10(2):139-45. Disponível em: http://www.ncbi.nlm.nih.gov/pubmed/11862503.

28. Kim Y, Morrow GR. Changes in family relationships affect the development of chemotherapy-related nausea symptoms. Support Care Cancer. [Internet]. 2003
[Acesso 27 ago 2013];11(3):171-7. Disponível em: http://www.ncbi.nlm.nih.gov/pubmed/12618927.

29. Glaus A, Knipping C, Morant R, Böhme C, Lebert B, Beldermann $F$, et al. Chemotherapy-induced nausea and vomiting in routine practice: a European perspective. Support Care Cancer. [Internet]. 2004 [Acesso 22 out 2013];12(10):708-15. Disponível em: http://link. springer.com/article/10.1007\%2Fs00520-004-0662-x.

30. Roscoe JA, Bushunow P, Morrow GR, Hickok JT, Kuebler $\mathrm{PJ}$, Jacobs $\mathrm{A}$, et al. Patient Expectation is a strong predictor of severe nausea after chemotherapy. Cancer. [Internet]. 2004 [Acesso 27 ago 2013];101(11):27018. Disponível em: http://onlinelibrary.wiley.com/ doi/10.1002/cncr.20718/pdf.

31. Bloechl-Daum B, Deuson RR, Mavros P, Hansen M, Herrstedt J. Delayed nausea and vomiting continue to reduce patients'quality of life after highly and moderately emetogenic chemotherapy despite antiemetic treatment. ] Clin Oncol. [Internet]. 2006 [Acesso 15 jun 2013];24(27):4472-8. Disponível em: http://jco. ascopubs.org/content/24/27/4472.full.pdf+html.

32. Pradermdee $\mathrm{P}$, Manusirivithaya $\mathrm{S}$, Tangjitgamol S, Thavaramara T, Sukwattana P. Antiemetic effect of ondansetron and dexamethasone in gynecologic malignant patients receiving chemotherapy. J Med Assoc Thai. 2006;89 Supl.4:S29-36.

33. Higgins SC, Montgomery GH, Bovbjerg DH. Distress before chemotherapy predicts delayed but not acute nausea. Support Care Cancer. [Internet]. 2006 [Acesso 27 ago 2013];15(2):171-7. Disponível em: http://link. springer.com/article/10.1007\%2Fs00520-006-0113-y. 34. Kim Y, Morrow GR. The effects of family support, anxiety, and post-treatment nausea on the development of anticipatory nausea: a latent growth model. J Pain Symptom Manage. [Internet]. 2007 [Acesso 8 out 2013];34(3):265-76. Diponível em: http://www. jpsmjournal.com/article/S0885-3924(07)00322-3/pdf. 35. Shelke AR, Roscoe JA, Morrow GR, Colman LK, Banerjee TK, Kirshner JJ. Effect of a nausea expectancy manipulation on chemotherapy-induced nausea: a University of Rochester Cancer Center community clinical oncology program study. J Pain Symptom Manage. [Internet]. 2008 [Acesso 21 out 2013];35(4):381-7. doi: 10.1016/j.jpainsymman.2007.05.008. Disponível em: http://www.ncbi.nlm.nih.gov/pmc/articles/ PMC3027302/pdf/nihms261794.pdf.

36. Shih V, Wan HS, Chan A. Clinical predictors of chemotherapy-induced nausea and vomiting in breast cancer patients receiving adjuvant doxorubicin and cyclophosphamide. Ann Pharmacother. [Internet]. 2009 [Acesso 15 jul 2013];43(3):444-52. doi: 10.1345/ aph.1L437. Disponível em: http://aop.sagepub.com/ content/43/3/444. full.pdf+html?frame=header. 
37. Roscoe JA, Morrow GR, Colagiuri B, Heckler CE, Pudlo $B D$, Colman $L$, et al. Insight in the prediction of chemotherapy-induced nausea. Support Care Cancer. [Internet]. 2010 [Acesso 8 out 2013];18(7):869-76. doi: 10.1007/s00520-009-0723-2. Disponível em: http:// www.ncbi.nlm.nih.gov/pmc/articles/PMC3017350/pdf/ nihms259673.pdf.

38. Huertas-Fernández MJ, Martínez-Bautista MJ, Sánchez-Martínez I, Zarzuela-Ramírez M, BaenaCañada JM. Análisis de la efectividad de un protocolo de antiemesis implantado en la Unidad de Oncologia. Farm Hosp. [Internet]. 2010 [Acesso 13 ago 2013];34(3):12538. doi: 10.1016/j.farma.2009.11.001. Disponível em: http://apps.elsevier.es/watermark/ctl_ servlet?_f=10\&pident_articulo=13150710\&pident usuario $=0 \&$ pcontactid $=\&$ pident_revista $=121 \&$ ty $=126 \&$ accion $=$ L\&origen $=$ zonadelectura $\& w e b=w w w$.elsevier.es \&lan $=$ es\&fichero $=121 v 34$ n03a13150710pdf001.pdf.

39. Hassan BAR, Yusoff ZBM. Negative impact of chemotherapy on breast cancer patients QOL - utility of antiemetic treatment guidelines and the role of race. Asian Pac J Cancer Prev. [Internet]. 2010 [Acesso 22 jul 2013];11(6):1523-7. Disponível em: http://www. apocpcontrol.org/paper_file/issue_abs/Volume11_ No6/c\%201523-27\%2010.22\%20Bassam\%20Hassan. pdf.

40. Fernández-Ortega $P$, Caloto MT, Chirveches E, Marquilles R, Francisco JS, Quesada A, et al. Chemotherapy-induced nausea and vomiting in clinical practice: impact on patients' quality of life. Support Care Cancer. [Internet]. 2012 [Acesso 15 ago 2013]; 20(12):3141-8. doi: 10.1007/s00520-012-1448-1. Disponível em: http://link.springer.com/article/10.1007 \%2Fs00520-012-1448-1.

41. Feinberg BA, Gilmore JW, Haislip S, Wentworth C, Burke TA. Incidence and risk factors for chemotherapyinduced nausea or vomiting following highly or moderately emetogenic chemotherapy in community oncology practice. Commun Oncol. 2010;7(8):347-54. 42. Hilarius DL, Kloeg $P H$, Wall E, Heuvel J, Gundy CM, Aaronson NK. Chemotherapy-induced nausea and vomiting in daily clinical practice: a community hospitalbased study. Support Care Cancer. [Internet]. 2012 [Acesso 22 jul 2013];20(1):107-17.doi: 10.1007/ s00520-010-1073-9. Disponível em: http://www.ncbi. nlm.nih.gov/pmc/articles/PMC3223596/pdf/520_2010_ Article_1073.pdf.

43. Molassiotis A, Aapro M, Dicato M, Gascon P, Novoa $\mathrm{SA}$, Isambert $\mathrm{N}$, et al. Evaluation of Risk Factors Predicting Chemotherapy-Related Nausea and Vomiting: Results From a European Prospective Observational Study. J Pain Symptom Manage. [Internet]. Madison; 2013 [Acesso 13 ago 2013];47(5):839-48. Disponível em: http://www.jpsmjournal.com/article/S08853924(13)00397-7/pdf.

44. Furman JM, Marcus DA, Balaban C. D Rizatriptan reduces vestibular-induced motion sickness in migraineurs. J Headache Pain. [Internet]. 2011 [Acesso 15 out 2013];12:81-88. Disponível em: http:// www.ncbi.nlm.nih.gov/pmc/articles/PMC3072502/ pdf/10194_2010_Article_250.pdf.

45. Spinks A, WASIAK J. Scopolamine (hyoscine) for preventing and treating motion sickness. Cochrane Database Syst Rev. [Internet]. 2011 [Acesso 03 jan 2014];6. Disponível em: http://www.thecochranelibrary. com.

46. Ferreira $A B H$. Significado de náusea. In: Ferreira $A B H$. Dicionário do Aurélio. [Internet] 2014. [Acesso 13 mar 2014]. Disponível em: http://www.dicionariodoaurelio. com/Nausea.html

47. Mizuno M, Hiura M, Kikkawa F, Numa F, Yaegashi $\mathrm{N}$, Narahara $\mathrm{H}$ et al A prospective observational study on chemotherapy-induced nausea and vomiting (CINV) in patients with gynecologic cancer by the CINV Study Group of Japan. Gynecol Oncol. [Internet]. 2016 [Acesso 15 fev 2016];140(3):559-64. doi: 10.1016/j.ygyno.2015.12.029. Disponível em: http:// www.gynecologiconcology-online.net/article/S00908258(15)30232-8/pdf.

48. BONASSA EMA, GATO MIR. Terapêutica oncológica para enfermeiros e farmacêuticos. 4. ed. São Paulo: Atheneu; 2012.

49. Sekine I, Segawa Y, Kubota K, Saeki T. Risk factors of chemotherapy-induced nausea and vomiting: index for personalized antiemetic prophylaxis. Cancer Sci. [Internet]. 2013 [Acesso $17 \mathrm{fev}$ 2016];104(6):7117. doi: 10.1111/cas.12146. Disponível em: http:// onlinelibrary.wiley.com/doi/10.1111/cas.12146/epdf.

50. Akechi T, Okuyama T, Endo C, Sagawa R, Uchida M, Nakaguchi T. Anticipatory nausea among ambulatory cancer patients undergoing chemotherapy: prevalence, associated factors, and impact on quality of life. Cancer Sci. [Internet]. 2010 [Acesso $17 \mathrm{fev}$ 2016];101(12):2596-600. doi: 10.1111/j.13497006.2010.01718.x. Disponível em: http://onlinelibrary. wiley.com/doi/10.1111/j.1349-7006.2010.01718.x/ epdf.

51. Pirri C, Katris P, Trotter J, Bayliss E, Bennett R, Drummond $\mathrm{P}$. Risk factors at pretreatment predicting treatment-induced nausea and vomiting in Australian cancer patients: a prospective, longitudinal, observational study. Support Care Cancer. [Internet]. 2011 [Acesso

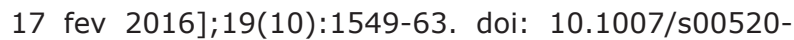
010-0982-y. Disponível em: http://link.springer.com/ article/10.1007\%2Fs00520-010-0982-y. 
52. Yap KY, Low XH, Chui WK, Chan A. Computational prediction of state anxiety in asian patients with cancer susceptible to chemotherapy-induced nausea and vomiting. J Clin Psychopharmacol. [Internet]. 2012 [Acesso 20 set 2013];32(2):207-17. doi: 10.1097/ JCP.0b013e31824888a1. Disponível em: http://www. ncbi.nlm.nih.gov/pubmed/22367655.

53. Booth CM, Clemons M, Dranitsaris G, Joy A, Young $S$, Callaghan $W$, et al. Chemotherapy-induced nausea and vomiting in breast cancer patients: a prospective observational study. J Support Oncol. [Internet]. 2007 [Acesso 15 fev 2016];5(8):374-80. Disponível em: http://www.ncbi.nlm.nih.gov/pubmed/17944146.

54. Di Mattei VE, Carnelli L, Carrara L, Bernardi M, Crespi G, Rancoita PM, et al. Chemotherapy-Induced Nausea and Vomiting in Women With Gynecological Cancer: A Preliminary Single-Center Study Investigating Medical and Psychosocial Risk Factors. Cancer Nurs. [Internet]. 2016 [Acesso 20 fev 2016]; Disponível em: http://www. ncbi.nlm.nih.gov/pubmed/26895414.

55. Roscoe JA, Morrow GR, Aapro MS, Molassiotis A, Olver I. Anticipatory Nausea and Vomiting. Support Care Cancer. [Internet]. 2011 [Acesso 22 jul 2013];19(10):1533-8. doi: 10.1007/s00520-0100980-0 Disponível em: http://www.ncbi.nlm.nih.gov/ pmc/articles/PMC3136579/pdf/nihms259633.pdf.

56. Kamen C, Tejani MA, Chandwani K, Janelsins M, Peoples AR, Roscoe JA, et al. Anticipatory nausea and vomiting due to chemotherapy. Eur J Pharmacol. [Internet]. 2014 [Acesso 15 fev 2016];5(722):1729. Disponível em: http://www.ncbi.nlm.nih.gov/pmc/ articles/PMC3880638/pdf/nihms-489182.pdf.

57. Colagiuri B, Roscoe JA, Morrow GR, Atkins JN, Giguere JK, Colman LK. How do patient expectancies, quality of life, and postchemotherapy nausea interrelate? Cancer. [Internet]. 2008 [Acesso 20 set 2013] ;113(3):65461. doi: 10.1002/cncr.23594. Disponível em: http:// www.ncbi.nlm.nih.gov/pmc/articles/PMC3079444/pdf/ nihms261787.pdf.
Copyright @ 2016 Revista Latino-Americana de Enfermagem This is an Open Access article distributed under the terms of the Creative Commons (CC BY).

This license lets others distribute, remix, tweak, and build upon your work, even commercially, as long as they credit you for the original creation. This is the most accommodating of licenses offered. Recommended for maximum dissemination and use of licensed materials. 